\title{
An attempt to revitalize part of an island in a new integrated system
}

\author{
M. Şahin \\ Yeditepe University, Faculty of Architecture, Istanbul, Turkey
}

\begin{abstract}
The main objective of this paper is to represent a revitalization project, aiming at recombining all valuable yet disintegrated cultural and natural components of a certain place, in a new coherent system. Covering 23 acres of land in a non-populated part of the island of Büyükada (Prinkipo), one of the few islands boasted by Istanbul, the private property in question has now been the subject of a revitalization project. The premises include two dilapidated ancient brick furnaces, a farm, a farmhouse, a family manor in a relatively fit state (the latter converted from a farm building in 1936 by Sedad Hakkı Eldem, one of the most prominent figures in modern Turkish architecture), a large vineyard once used by monks of the nearby St. George Monastery, and diverse flora and fauna. Firstly, all the natural and cultural aspects of the site, having evolved over a long period of time, were registered and re-evaluated by the owners, artists, architecture students and experts in the interrelated disciplines of archeology, architecture, landscaping, tourism and engineering. Secondly, all the rundown components of the site were remapped and redesigned to yield a new meaning, in an attempt to create physical, visual, functional and economic integrity, consequent to considerable discussion regarding relevant issues, such as sustainable development, revitalization and adaptive re-use, restoration and development. While preserving the distinct character of the place with a minimum of intervention, a number of fruitful propositions were developed. This paper demonstrates the indigenous identity of the island along with observations and analysis of the premises and their evaluation in many respects, as well as the system considered for an environmentally-friendly revitalization project carried out through a participatory approach.
\end{abstract}

Keywords: revitalization, integration, restoration, self-sustainability. 


\section{Introduction}

The Istanbul or Princes' Islands are an archipelago situated on a shallow shelf roughly ten nautical miles from the mainland in the Sea of Marmara, which lies south of the Kocaeli Peninsula, the latter also including the Asian side of Istanbul. Büyükada (Prinkipo) is the largest of the Princes' Islands and their administrative center [1]. Of the nine islands, it is one of the five that are inhabitable. A renewal project located on the occupied western part of this island, the integrity of which had been lost over the years, began with architectural restoration in a large forested and agricultural area and was transformed into a unified project of improvement and revitalization, which embraced other components of the surroundings as well.

The site involved a multifaceted effort of long duration, and its redefinition began with a visit and subsequent preliminary reports by experts and other workers from a number of different disciplines. This paper sets forth the causes for disruption of the self-sustaining link of the site while presenting the place in its spatio-temporal dimension with a view to making it more comprehensible. It also explains the design intent of the revitalization project, and aims at using this opportunity to encourage further participation.

\section{Distinct character of the island of Büyükada/Prinkipo}

With an area of roughly six square miles, until the turn of the 20th century Büyükada, like the four small islands around it - Heybeliada (Halki), Burgazadası (Antigoni), Kınalıada (Proti) and Sedefadası (Terebintos) - was used for occupation and as a summer resort by minorities (Armenians, Jews and especially Greeks), being home to their religious training and activities thanks to its shrines, monasteries, churches, and schools of divinity. The islands have known a multitude of names. Aristotle called them "the Halkedons", the Greek philosopher Artemidoros "the Pitiusas" (Pine-covered), and the Roman naturalist Pinius "the Propontidas" (Islands of the Marmara). Then along came the Byzantines, who opted for the Princes' Islands, or "Papadonisia" (the Islands of Priests or Monks) because of the monks who dwelt there, while the historian Hammer chose "Les Isles des Saints", Thomas Allom "the Demonesca", and the Turks "the Red Islands" due to the color of their soil [2].

Estimated at some three thousand in the first half of the 19th century, the population of Büyükada rose when ferry runs to the islands began midway through the same century, and by the turn of the 20th century had surpassed five thousand [3]. During the past century the island has become a summer resort popular with the city's well-to-do aristocrats (including people of Muslim as well as Christian and Jewish descent). It was also during these decades that the once predominant wooden architecture of the island began to give way gradually to masonry constructions and indeed a few multistoried apartments [2].

The island boasts various Byzantine and Ottoman remains and buildings, and on it Orthodox monasteries, a Jewish synagogue, an Armenian Catholic church, two Greek Orthodox churches, a Roman Catholic church and three mosques 


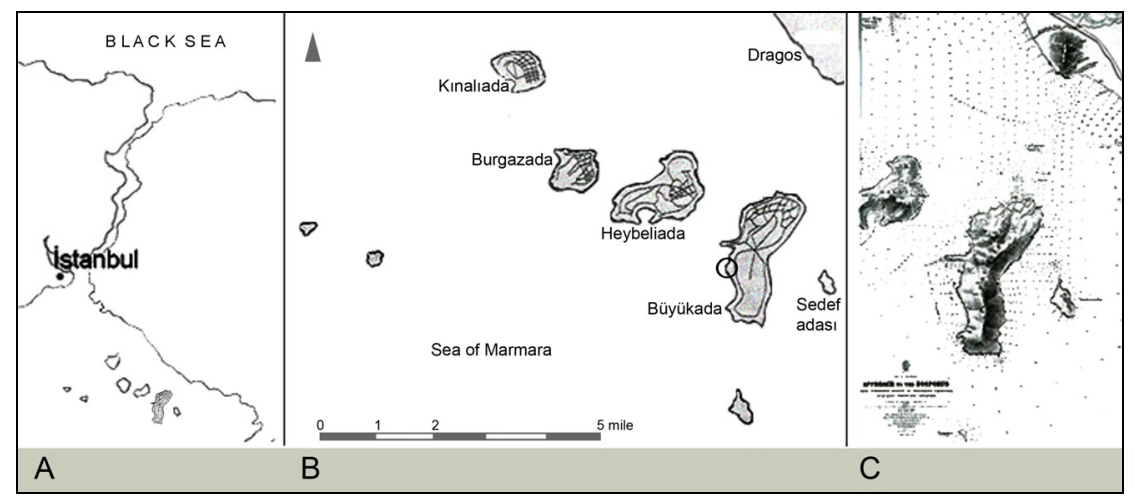

Figure 1: A-B: Princes' Islands and the location of the site in question; C: Büyükada on the map published in 1887 (London, British Library [2]).

actively serve a population of roughly 7,500 (said population figure reflecting the inactive season and hitting 65,000 during the summer) [3].

The elements that determine the nature of the island and give it its distinct character can be listed as follows:

- Rich vegetation coupled with a variegated climate and air that is cleaner than that in the city.

- An architectural fabric made up of numerous buildings of varying scale and typology, many of them historically significant and belonging to a number of cultures, which are better preserved than their counterparts in the city.

- A plethora of original wooden buildings, ranging from the plainest to ornate examples of the Art-Nouveau style.

- In terms of the spirit of place, an extraordinary character despite the island's proximity to the city.

- An established image of the island as a place for enjoyment, entertainment, rest and clean air, with the elements of said image still intact despite undergoing a certain amount of erosion.

- Absence of the roar and other noise heard/felt constantly in the background of the city. During the season which brings a concentration of visitors, there is a difference that could be qualified as noise, but it conveys such elements as merriment, fun-loving and high spirits, thanks to which it is less disturbing. (The site in question, being far from the center, is the haunt of silence year round).

- The phaetons used on an island where motor vehicles are prohibited, coupled to the smell of horse manure, which has increased in recent years parallel to a rise in the number of these carriages.

- A high risk of earthquake stemming from proximity to the fault, which runs the length of the Sea of Marmara south of the island. 
Consisting of two hills joined in a north-south orientation by a saddle, the island is 2,2 miles long and varies in width from 0.6 to 1,2 miles. Ísatepesi (Hristos Hill), on which stands Hristos Monastery and Church, is 530 feet high, while to the south rises Yücetepe (Ayia Yorgi Hill), 660 feet high (making it the highest hill on all the islands) and home to St. George (Ayia Yorgi) Monastery [4].

In the course of history the chief pursuits on the island, especially on monastery land, have been farming, grape-growing, livestock breeding and fishing. During Ottoman times a way of life centered on these pursuits and functions persisted until the mid-19th century; the tradition of grape growing and winemaking endured, although the monopoly of the monks and monasteries yielded to the control of wealthy Greek and French wine merchants. The wine of Ayia Yorgi Church, located on Büyükada's hill of the same name, was famous in the 19th and 20th centuries, the slopes of the hills on which the church stands being clad in vineyards. [1]. The site which is the subject of this project lies on the western slope of the latter hill, a slope which stretches all the way to the sea.

\section{Description of the site}

The site under discussion is a vineyard, one of those in an area called Eskibağ (Old Vineyard) adjacent to the lands of the Ayios Yorgios Monastery, which stands at the top of the hill. This 23-acre property stretches along the shore on a gentle slope facing the totally uninhabited islands of Yassiada (Plati) and Sivriada (Ohia) as well as the southern tip of Heybeliada (Halki), the last-named being open to habitation. The site boasts Aegean flora, and today also features red pines, cypresses, mimosas, olive trees and various fruit trees plus lowgrowing vegetation where there were once vineyards.

Until the 1930s the site was marked by economic, natural and cultural integrity. A dramatic change has been undergone in the site and its buildings, starting with a switch from agricultural use to one that was strictly residential.

No documentation exists concerning the site, apart from photos taken after 1935, oral history, and items mentioned in the sales contract about natural and cultural features of the property.

The site, which was taken under protection and declared a landmark in the 1990s, boasts two ancient brick furnaces, a farm, a farmhouse, and a family manor that was converted from a wine house in 1936. The family manor, which is registered and in quite good condition, is currently being used mainly as a weekend home. One building, formerly used as a stable and dilapidated like all the remaining buildings on the site, has a section which has been repaired in an ad hoc manner, where a family that looks after the property dwells the year round.

Rural in character, the garden is graced neither by any road of monumental impact nor by any egregious landscaping. The entrance and on-property roads are dirt, unpaved by any other material. The site is girded by a number of retaining walls, installed by the former users when the land was used agriculturally. As in traditional gardens, that surrounding the building features 
pot flowers, small fruit trees and low-growing garden plants in a humble arrangement, while those areas more distant from the building offer a natural setting conducive to the presence of various flora and fauna.

\subsection{The natural setting [5]}

a. Local Climate:_The climate on the islands may be the same as that in the city of Istanbul, where the Black Sea climate reigns, but on the mainland high hills blunt the cold north winds that blow down the Bosphorus. In the autumn, winter and spring months the air is warmed by occasional southwesterly gales, while in the hot season there is a cooling offshore breeze. On the northern coastal strip of Büyükada there is a typical Black Sea climate, but the southern coastal strip boasts a Mediterranean climate peculiar locally to this region. Due to the topographical configuration and gentle slope (average slope: $20 \%$ ) in a westerly orientation, it is sheltered from the north wind and thus has a moderate microclimate, this in turn making possible the maximum use of solar energy.

b. Geological Structure: On the south coast of Büyükada, whose geological nature is shared by the Marmara Islands, ground movements and sedimentation have led to the formation of rocks, especially of limestone and sandstone, rising perpendicularly from the shore and covered by readily visible fissuring due to the presence of bacteria, algae, lichens and moss. The geological structure consists predominantly of rock formations rising from the Sea of Marmara basin and altered by water and wind erosion. Some 6-7 nautical miles offshore from the site passes the Northern Anatolian Fault, which runs the length of Anatolia, continuing out into the Aegean Sea and from there towards southern Greece.

c. Landscape: In the region where the site lies a local moderate climate and favorable winds permit Mediterranean flora to thrive, including scrub, red pine (Pinus brutia) and mimosa, while making of the islands a popular summer and recreation resort. The soil of these islands is rich in minerals and red due to the presence of iron oxide, and has been cultivated for trees, fruit, vegetables and flowers. The fissuring, which starts with the rock mass, continues in vegetated zones with microflora, macroflora and mesofauna. Whereas on Büyükada and the other islands the depth of the soil does not exceed 15-20 cm, in the Eski Bağ region it attains $30-40 \mathrm{~cm}$, and here fissuring takes place at a faster rate while the organic matter capacity and the soil's capacity for water retention are also greater. The soil is rich in mud with a high clay and sand content. Despite the rocky nature of the soil it is rich in plant nutrients, yet is found to be wanting in terms of organic matter. In the regions with historical lime quarries, the soil is rich in lime as well. The slope, gravity, wind and, in some places, water have led to erosion because of which the vegetal soil, sparse to begin with, runs off into the sea or collects at the feet of the slopes.

While on the greater part of the islands the predominating tree growth consists at the upper level of diseased, scrawny, unimposing red pines which have undergone collapse and have trunks that are undergrown in comparison with their height, and at the upper level of a small number of oaks (quercus coccifera) and rockroses (cistus villosus), in this region there are tall, gratifyingly healthy red pines, properly proportioned as to height and diameter, which are 
better developed than those we have just mentioned. In addition the olive, arbutus and cypress trees here are tall and healthy in their development. Meanwhile, on the steep slopes stretching parallel to the sea there is a plentiful growth of sedum (a kind of thornless cactus), seemingly created for the purpose of halting erosion, together with a great deal of seagrape and shrub; these plants protect the slopes from the effects of gravity and erosion. The mix ensures the hardiness of the trees in the face of natural disasters and climate change, as well as from the assault of the wind and the predations of insects.

The buildings stand in the middle part of the site. The plants and trees at the southwest end of the building provide shade from the western sun and at the same time are, in the summer, a source of "evaporative cooling". Below this area there is no hint of building except for two modest furnaces, which were situated nearby the sea, at the lower level of the site, indicating a plan to obtain a poetic scenery and strong feeling of gestalt.

The first major step that involved the site's landscaping was an inventory of trees. Within a coordinate system, the existence of 758 trees was established on the site, including 70 cypresses and 670 red pines. A great majority of the trees stand on the periphery of the site and on the declivity that descends to the sea, thus forming a buffer zone around the house.

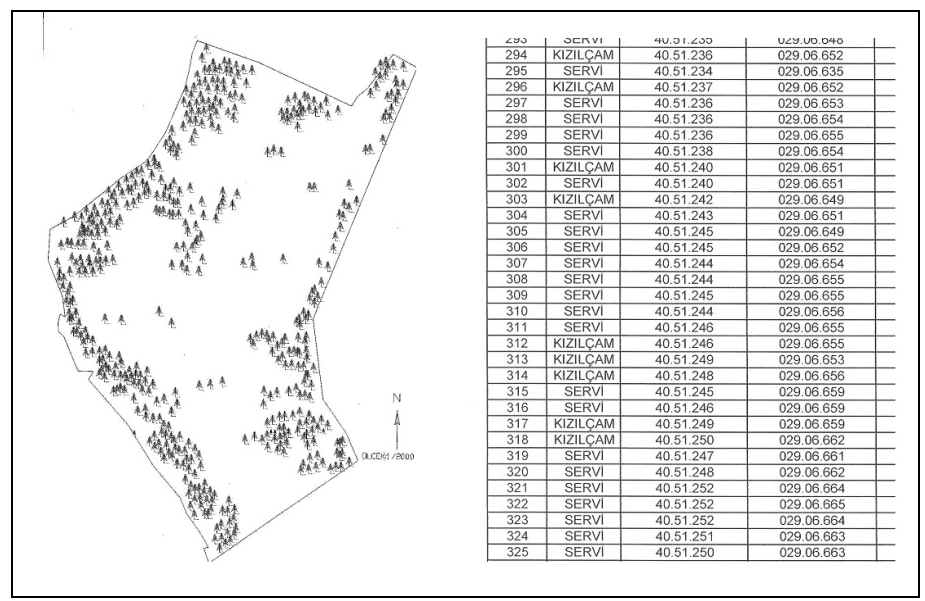

Figure 2: Distribution of the major trees on the site and a sample of the inventory study.

d. Waterfront: The shore is separated from the body of the site by a deep declivity. The site's pier is damaged and unfit for use. The northern shores of the islands, which face the city, have been heavily built up and have thus lost their natural character. The south shore of Büyükada, however, is exposed to the south wind, and the shoreline where the site in question is located, features pebbles and, at sea level, flat horizontal rock formations stretching parallel to the perpendicular rocks spoken of earlier. Thus the shore has retained its natural aspect. From the shoreline outward there is a strip of sea 30-40 feet wide covered 
with seaweed and reaching a depth of 10-12 feet, while the greatest depth attained is $190-220$ feet.

There is no written record of the lime quarry on the shore, or of the remains of the two brick furnaces. Since among locals the road running landward of the site is known as the "Kamino (Furnace) Road," it would appear that these structures are more than 80 years old. It is thought that an investigation of the history of these furnaces will also shed light on that of the island.

\subsection{Cultural aspect}

Made in the mid-30s, the sales contract reveals that in addition to the natural features of the site, the fields closely surrounding the buildings and house were still being farmed, and that there were still vineyards. When the property changed hands and an annex was attached to the existing vineyard house, which also underwent restoration and redesign, the site was turned into a resort, which could be said to have marked the beginning of the change that has continued to the present day. This building is used as a family residence, while the retaining walls which run parallel to its seaward-looking facade and to the slope not only set off areas suitable for farming, but at the same time prevent movement of the foundation toward the sea, on which side the inclination is greater.

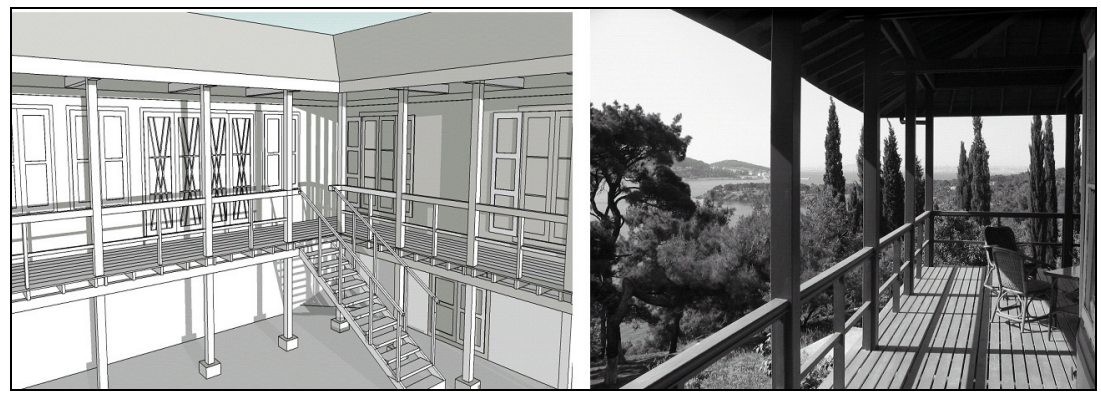

Figure 3: The wooden, pillared veranda with roof overhang.

The outer walls of the dwelling are of brick and stone, while the interior partition walls and the roofing structure are entirely of wood. A wooden, pillared veranda encloses the entire house in the direction of the view. The bearing walls are distinct from the partition walls in this structure, which has broad eaves, a hip roof, wooden interior walls, external stairs and pilotis architecture, with design features of coastal architecture, the traditional Anatolian home, Japanese architecture and the architectural principles of Le Corbusier. With its lightness of structure, modularity, spatial familiarity, flexibility, and unity of exterior and interior, coupled to the use of intermediary space (semi-open spaces), suitable orientation, possibility of interior cross-ventilation, relation between facade organization and orientation, the fact that rainwater is collected from the roof for storage in a basement cistern, the use of wood as a renewable material, and the comfort made available visually and in terms of use, it might be stated that the house is in harmony with the environment. 
As with traditional dwellings, this building has a flexibility enabling it to adjust to seasonal and daily differences in the weather. For example, while in the direction of the view the amply-windowed building shell allows for the admission of ample light, the broad-eaved semi-open space in front of it, coupled with the building's L shape and the spatial transitions, prevent overheating of the interior. One notes that the requisite number of window openings have been provided in the building shell and that where necessary shutters have been added to the windows. The unit, which was formerly used as a vineyard house, is occupied in the winter, and in the summer the living room, which was later built on, is also used.

As indicated above, when the building served as a vineyard house all the rainwater collected from the roof was stored in a cistern below the house the supply its general needs. For this a special detail was worked up for the junctions of the zinc gutters and drainpipes, but it turns out that this detail was altered during repairs. Considering that until recently there was no city waterpipe system on the island, this arrangement in one respect resulted in self-sustainability.

\subsection{Current infrastructure}

Year round there are regular ferry runs from the city to the island, where transportation is by phaeton due to the ban on motor vehicles. Although access to the site is possible via both sea and land, the ruined state of the existing pier, coupled to the steep incline from the shore, means that today people avail themselves of land access only.

The site has both electricity and a system of waterpipes. Clean water from the city is supplied via an underwater pipeline by the city waterworks company. In addition the site boasts seven clean-water wells and three cisterns with a combined capacity of 65 tons. Although there is a natural gas pipe system on the island, remoteness from the center means that no natural gas pipeline has yet been run into the site. Heating in the area is generally through fireplaces and stoves that burn fuel oil, coal and wood. Wastewater is currently disposed to the ancient underground sewage system. A solution to the problem of wastewater treatment is part of the engineering work that will go into the project.

\section{The holistic approach and design intent}

However much the island possesses a Gestalt quality which, considering spirit of place, is its predominant character, today the northern side facing the mainland, due to its climatic and spatial features resembles Istanbul in its urban character and the manner in which it functions. Nevertheless, with its microclimatic conditions, distinctive flora, visual character, unique historical development and the predominating nature of its architectural elements, the area may be considered as an unusual microenvironment, a system in itself.

"In an environmental totality, the practical and poetic are indissolubly linked" [6]. The integrated character of the place in the past was "a product of the climatic conditions and local use" [6]. The change that arose when the vineyard 
house began to be used for holidays interrupted human continuity, in other words cultural continuity, and this in turn led to environmental disintegration so that in the course of time the poetic unity of the site was undermined. Considering in particular the time when the place was a vineyard, it can be regarded, like many vernacular examples or countless traditional settlements in Anatolia, as an integrated site in terms of its use of the general principles of habitation (orientation toward the sunny south, a broad view of cultivated land and scenery) as well as all its economical, natural and cultural components including frugality, use of local/natural materials, use of ground and rain water, and design principles such as the organization of space and facades according to climatic conditions.

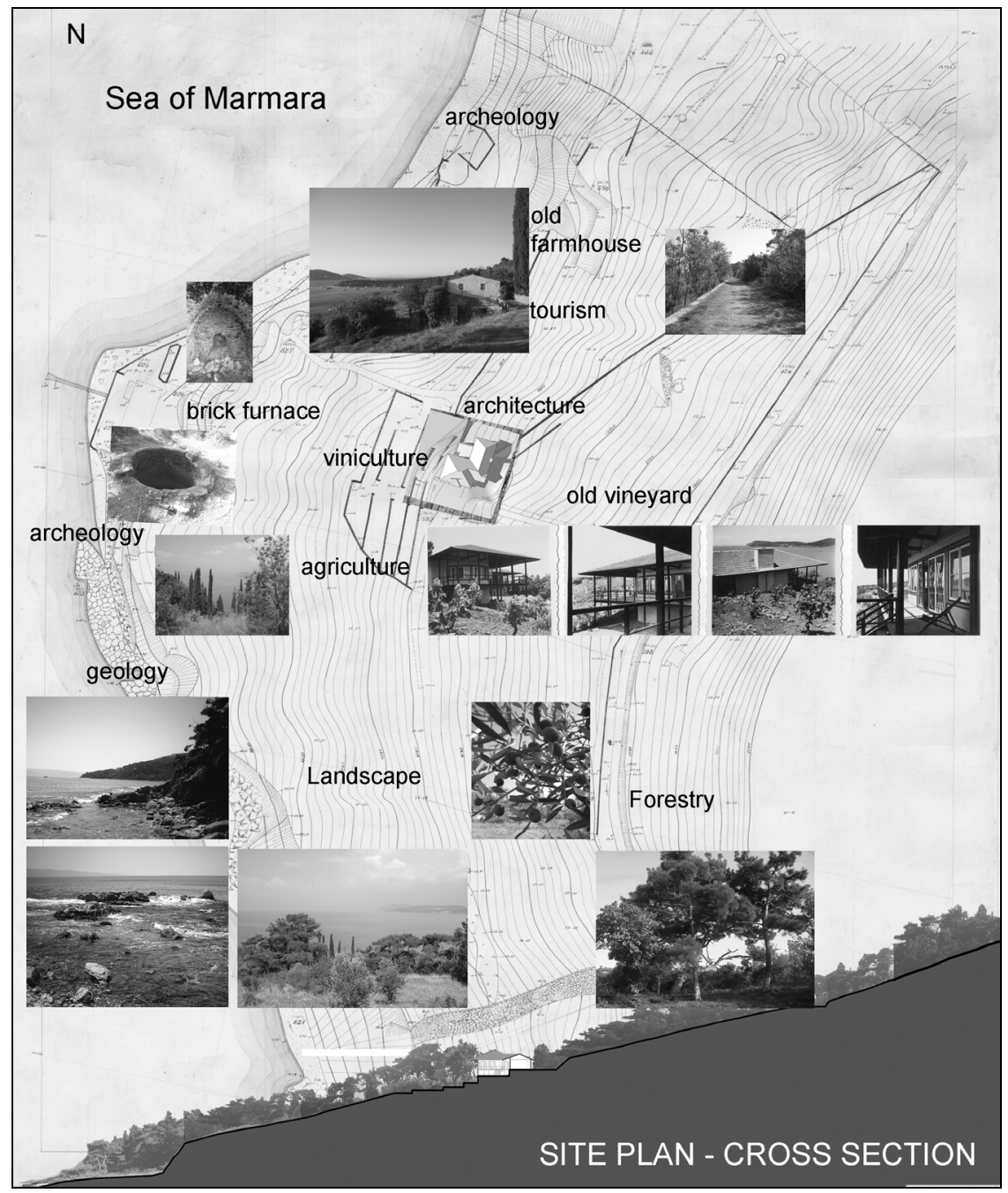

Figure 4: $\quad$ Basic interrelated components of the site. 
Today the site has lost this integrated character, but in the light of multifaceted analysis and assessment an attempt is being made to restore it, of course in a manner that sorts with present conditions. At the outset of this project an important source of motivation was furnished by the "poetic" significance of self-sustainability.

The renewal was, in the beginning, limited to architectural restoration. Bearing in mind the site's past, however, and its current situation, it was decided that such restoration would be meaningless without a holistic design. "Systems integration at the site level deals with issues of context: environmental, social, urban, cultural, and whatever special conditions are presented by the exact situation of the building project and its neighboring surroundings" [7]. Thus the objective became to work up a project where, just as in history, the site would be made into an entire pattern in which all elements were experienced as a mutual system, creating each other and being created within that system, with restoration and development embracing the site as a totality. The result was the formation of a flexible planning and working group made up of experts and participants from a range of disciplines, with architecture at the core.

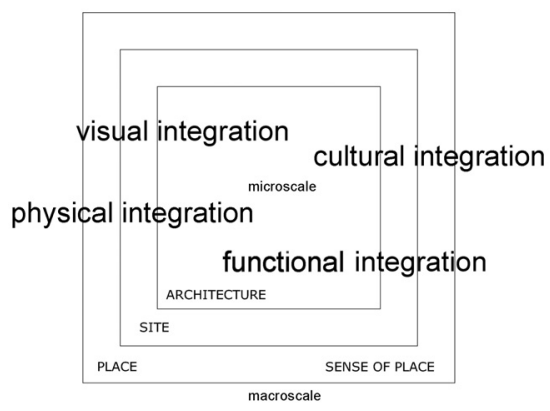

Figure 5: Graphic representation of integrated systems, which is a reinterpretation of Bahman's description of integration [7].

The design intent is based on two major notions, the first being selfsustainability, predicated on the use of renewable sources of energy coupled to conservation of nature and resources. The other notion is restoration of the buildings and historical human activities (such as grape harvesting and maritime trade) that were once part of the environment, of course in a fresh context. The accordance and integrity of the concept will be carefully re-examined so as to ensure compliance with the place and with standards set by the Board of Preservation of the Cultural and Natural Heritage in obtaining a permit for the master plan. With the preparation of the plan and reception of the requisite permits, the planning phase ends and the project enters the development phase. 


\section{Provisional results}

While those involved are certainly determined to revitalize the site and make it actively usable, the design decisions vis-à-vis the program and structural solutions are "flexible," as evinced in decisions of principle such as improving the place through a minimum of intervention and by integrating cultural, visual, physical and economic values, as well as in the set of specific provisional decisions taken in line with the reports which have been submitted. These decisions are as follows:

- In view of the fact that meteorological data concerning Istanbul and the island will be inadequate, to monitor weather conditions on the site itself and launch a specific operation to determine the effects there of climate change,

- To carry out a feasibility study regarding rehabilitation of the soil and trees on the site, especially the olive trees, as well as the replanting of a vineyard,

- While avoiding the pitfalls of such fashionable concepts as agrotourism and ecotourism, to ensure both cultural and economic self-sustainability as a result of low-intensity use of the site for educational purposes in the fields of architecture and landscaping/agriculture with children and teenagers in mind,

- To completely preserve the dwelling, which constitutes a landmark, and to set aside one part of it for use as a museum where old documents would be kept and displayed for the benefit of a limited number of visitors; to employ, in the minimum number of other small buildings on the site to be designated for restoration, the ecological ordering of space and use of materials peculiar to vernacular architecture, which have satisfied users of the building in question during the course of experience;

- Due to its structural system the building is highly vulnerable to damage in earthquakes, and because it is very near the North Anatolian Fault a detailed seismic evaluation is required. According to the Civil Engineering preliminary report the results of materials tests and an insitu tremor test should be used to work up a finite element model, while the building's earthquake behavior should be studied based on calculations using the acceleration spectrum that pertains to this particular building,

- To preserve, visually and physically, the rural character of the site, engaging in no construction apart from converting other run-down old buildings for day-trip use, taking care to remain faithful to their footprints,

- Considering the well-known difficulties of transportation and construction that are part of life on the island, to give priority on the site to light structures and systems of construction based on assembly, such as prefabrication and modularity, 
- To bring back structural and technical details encountered in old plans and produced for the purpose of storing and using rainwater,

- Considering the restricted budget and the main objective of the study, a decision has been made to give priority to passive solar systems and natural materials, resorting to active solar systems only where necessary. Furthermore, other renewable energy sources will be carefully considered, along with waste treatment, and built in to the master plan.

\section{Acknowledgements}

My thanks go to A. Fethi Okyar, Timurhan Timur, Yüksel Özcan, and Başak Çakmak, for the support they have given to this project through providing reports.

\section{References}

[1] Gökçen, T., Adalar, Dünden Bugüne İstanbul Ansiklopedisi, Türkiye Ekonomik ve Toplumsal Tarih Vakfı Yayınları, Vol.1, pp.66-75, 1993.

[2] Tuğlac1, P., Tarih Boyunca İstanbul Adaları, Say Yayınları, İstanbul, Vol. I, pp.19-23, 1995.

[3] http://www.adalar.bel.tr./nufus. (Web site visited on 12 September 2008)

[4] Poridis, A., Istanbul Adaları'nın Sosyal ve Fiziksel Gelişiminin Analizi ile Fiziksel Çevrenin Değerlendirilmesine İlişkin Sistematik Bir Yaklaşım, Doktora Tezi, YTU, Fen Bilimleri Enstitüsü, İstanbul, 1999.

[5] This section is based on a report by Yüksel Özcan, from The Ministry of Environment and Forestry of Turkish Republic, 10/2008.

[6] Norberg,-Schulz, C., Architecture: Presence, Language and Place, Skıra editore, Milan, p.239, 2000.

[7] Bachman, L., Integrated Buildings, John Wiley \& Sons, Inc., Hoboken, New Jersey, 2003. 